\title{
REVIEW OF THE REGULATORY DOCUMENTS ON TAXATION ISSUES IN JUNE-JULY 2013
}

\author{
L.Anisimova
}

In the period under review, the Government of the Russian Federation has confirmed its position which consists in the fact that in the next few years it will not change the existing rules of taxation. At the same time, the business has become more active in promotion of proposals to reduce a tax load: the platform of the All-Russia People's Front, a new political alliance is actively used for putting forward initiatives as regards tax holidays, privileges are proposed to financial market participants within the frameworks of realization of the RF Government's idea to create the MFC in the territory of the Russian Federation and initiatives on adjustment of the existing scheme of taxation in the oil industry are voiced ${ }^{1}$. In our opinion, at present it is important to be cautious in promotion and realization of any financial initiatives as the economy of the Russian Federation has to go through an inevitable stage of market adaptation and losses of budget revenues are as undesirable as an increase in the tax burden.

Unfortunately, it is to be stated that as the Government of the Russian Federation and the business have failed so far to develop a concerted vision of the current situation, the optimal scheme of mandatory payments and correlation between budget revenues and expenditures in case of approval of one or other proposals made by either the business or officials possibilities of fluctuations in the budget revenue base and losses may turn out to be too high. Underestimation in planning of revenues for 2013 and expenses on compensation of VAT as regards large commissioned projects related to Russia's participation in the APEC and holding of the Olympic Games in Sochi in combination with fundamental decisions of late in the sphere of taxation, such as payment of the profit tax by a consolidated group of payers (which measure permits to "close" profit of some entities by losses of other) has sped up a drop in the budget revenue base justified by a stagnation in the economy. In its turn, the prevailing threat of growth in the rates of insurance contributions and tariffs of housing and public utilities increase financial risks of investors, which situation slows down the influx of capital to industry. The threat of shortfalls of oil funds to the budget due to tax initiatives of producers of hydrocarbons aggravates social tensions because for the purpose of preserving the social stability the Government of the Russian Federation has to increase all the time the labor remuneration in the budget sphere which situation is a key factor behind the growing inflation rate (a classical spiral: wages and salaries - prices). It is to be noted that credit resources of state-owned banks happened to be involved in non-

1 What is meant here is an appeal by the management of OAO Rosneft to the Government of the RF to reduce a tax burden on oil production from $55 \%$ to $45 \%$ in the period till 2020 ; proposal by the Delovaya Rossia on provision of two-year tax holidays to individuals who engage for the first time in business activities and other. repayable lending to entities which are characterized as backbone state corporations, while efforts to attract funds on the bond market may turn out to become bubbles $^{2}$ due to a drop in returns on investments in Russian bonds.

At present, the Government of the Russian Federation relates the revival of the market to emergence of new real tradable market assets (one of such assets is agricultural produce) and looks forward to the first performance results of former budget-funded entities in the new economic conditions within the frameworks of the legislation on non-profit organizations or in the form of joint-stock companies. It is to be reminded that in 2012 the Government of the Russian Federation carried out a key economic reform by granting former budget-funded entities an opportunity to decide in conditions of real competitive environment their future faith for themselves, that is, either go bankrupt or start producing competitive goods (jobs and services) - in other words, compete properly for consumers. The first year of adaptation to market conditions is coming to an end. The more so, it is important to approach carefully any initiatives in the sphere of finance and business as they may deeply destabilize the general economic situation.

It seems that the initiative of OAO Rosneft as regards reduction of federal budget revenues is caused

2 It seems that in July 2013 the approval of such amendments to the Tax Code of the RF as cancel the tax on interests on Eurobonds for nonresidents registered as taxpayers in the territory of states which the Russian Federation concluded double taxation agreements with was made primarily to support the Russian stock market which in May-June 2013 demonstrated a dramatic drop in prices on bonds (see Website of Gazeta.Ru of July 24, 2013, "Putin Signed the Law on Taxation of Eurobonds" ; M. Overchenko, "No Russian Companies in the World's Top 50", vedomosti.ru, July 24, 2013; D.Borisyak: "Cheap Bonds Cost Bankers \$430m", vedomosti. ru, July 24, 2013). 
by the fact that at that stage the country's leadership included in the list of priority investment projects funded out of the National Welfare Fund the development of railway transport service and building of motorways in the Moscow Region. Though OAO Rosneft has managed to attract credit resources of Chinese consumers of hydrocarbons by striking a large deal at the St. Petersburg Economic Forum in June 2013, but unlike railway men it does not receive the money for free (that is, out of the budget or sovereign funds), but on a returnable and payable basis, so, OAO Rosneft probably decided to receive an economic support from the government in the form of tax privileges. It is to be noted that OAO Rosneft keeps pursuing the policy of buying titles to oil deposits.

In its turn, in 2014 a fee for heavy-duty trucks' transit on roads of federal importance - the above duty was introduced into Federal law No.68-FZ of April 6, 2011 - starts to be paid to the budget. The amount and procedure for payment of the fee as regards federal roads is set by resolution No.504 of June 14, 2013 of the Government of the Russian Federation. Starting from November 1, 2014, the fee will be paid by advance payments proceeding from the planned route of the vehicle and is calculated on the basis of $\mathrm{Rb} 3.5$ per $1 \mathrm{~km}$ of transit by a vehicle weighing over 12 tons on roads of federal importance (as regards transit on roads of regional importance the rules and amount of the payment are likely to be determined by regional authorities). The purpose of collection of the duty is compensation of the damage caused to general-purpose motorways by heavy-tonnage trucks. It is to be reminded that container carriers may have the weight of 20 tons, 40 tons and 60 tons. According to the Rules, differentiation of the fee depending on the excess of the actual weight of the transport vehicle over the permitted one is not provided for, that is, transport vehicles of any weight over 12 tons will pay a standard fee of $\mathrm{Rb} 3.5$ per $1 \mathrm{~km}$. Let's calculate an approximate load on entrepreneurs' expenses due to introduction of that fee and on the basis of the given parameters.

As of January 1, 2013, in Russia the fleet of auto vehicles amounted to $47.9 \mathrm{~m}$ units ${ }^{1}$. Cargo vehicles $(5.7 \mathrm{~m}$ units) accounted for nearly $12 \%$ of the national fleet ${ }^{2}$.

\footnotetext{
1 See: Website: autostat.ru /catalog/product/146/\#

2 See: A. Grammatchikov: "We Have To Be in Russia", Expert Avto Magazine, No. 4 (135) of June 17, 2013, published on the Website of Expert.ru/magazine_auto/2013/04/v-rossii-myi-obyazanyi-byit/ media/198309/. In 2012, sales of heavy-duty trucks (with weight over 16 tons) amounted to 100,000 units a year (against 80,000 a year before 2008). So, number of heavy-duty trucks in Russia can be estimated at $80,000 * 10$ years $=800,000$ units, while that with taking into account intermediate-tonnage trucks with weight from 12 tons to 16 tons, at over a million units.
}

Let's make a simple calculation on the basis of the number of heavy-duty vehicles on Russian roads $-1 \mathrm{~m}$ units (subscript calculation) -- and a mean path of $80,000 \mathrm{~km}$ ( $50 \mathrm{~km}$ per hr* $8 \mathrm{hrs} * 200$ days). As a result, the expenses will amount to about $\mathrm{Rb} 300,000$ per heavy-duty truck, which value is equal to mobilization of additional $\mathrm{Rb} 300,000$ to the budget. Such expenses (calculated on the most favorable basis) are comparable to costs related to employment of one additional driver a year per truck. It is believed that in reality entities will have to pay more, it is to be noted that those costs will be shifted on consumers and included in transportation costs. It is likely that payments will amount to $\mathrm{Rb} 1$ trillion (the fleet of trucks which have to make such payments is likely to exceed the level of $1 \mathrm{~m}$ units and working parameters of trucks will evidently be much more than 200 days and 8 hours a day). The problem may become more complicated taking into account the need of an advance payment for the transit.

In addition to Russian trucks, there are heavy-duty trucks of foreign suppliers on Russian roads and according to the concept of the authors of the payment they will have to pay as well to the Russian budget system. However, for the purpose of ensuring equal competition some EU countries take counter measures to adjust cargo transportation terms: for example, Finland has introduced "mirror" rules for Russian carriers. It means that in case of a necessary transfer by Russian importers to ex-factory terms of collection of goods (for example, in case Finnish suppliers give up the scheme of Franco-station destination as exceedingly expensive as compared to relations with other trade partners) Russian buyers will have to pay yet similar transportation costs to the budget of Finland. Generally, in WTO conditions it is necessary to abandon exotic payments and fees as they are easily blocked by counter (mirror) decisions and, as a result, the market of the originator of such fees becomes less attractive and competitive as compared to other markets, while residents working in that market usually incur additional costs on other markets due to mirror rules being applied to them. As a result, competitive edge of domestic producers of goods will be artificially lowered.

In such conditions, with risks of costs fluctuations (up to 7-8\% of federal budget revenues) introduction of tax holidays for newly-started businesses ${ }^{3}$ is unlikely

3 I. Grigorieva: "Business Will be Exempted from Taxes". On July 11, 2013, D. Medvedev, Chairman of the Government of the Russian Federation instructed the Ministry of Finance, the Ministry of Economic Development and the Ministry of Labor together with Delovaya Rossia (which is the author of the proposal) to exempt newly-registered individual entrepreneurs (IE) from all the taxes 
to contribute to considerable growth in their number as representatives of the Delovaya Rossia believe. The more so, the Ministry of Finance of the Russian Federation is unlikely to introduce tax holidays without limitation of the volumes of merchandise turnover per newly registered entrepreneur - otherwise "knowledgeable" businessmen will manage to withdraw through the balance of a newly registered business any profit amounts without paying taxes.

To sum it up, it is necessary to underline that both the Government and the business should impose a temporary moratorium on financial initiatives at least for the period of adaptation of the former budgetfunded economy to the market. As regards payment for transit of heavy-duty and medium-duty trucks, there is little time left for evaluation of the consequences of introduction of that fee for the Russian economy - from November 1, 2014 the above payment will become a real income of both federal and regional budgets. It can be canceled only in case regional budgets are compensated losses on that payment at the expense of the federal budget.

In our view, it is important to give up mandatory payments attributed to costs - those payments will always result in a decrease in competitiveness of domestic producers of goods, as well as any tax privileges granted to individual groups of taxpayers will actually be used as channels for tax evasion ${ }^{1}$.

Another factor with consequences which are difficult to forecast is growth in a penalty load on the business. Federal Law No.134-FZ of June 28, 2013 was adopted in order to establish a detailed scheme of real-time and technical measures to prevent terrorism and illegal flight of capital from Russia by means of amendment of the tax legislation, customs legislation and the legislation in the sphere of social contributions to state extra-budgetary funds, financial monitoring and toughening of criminal and administrative punishment for committed violations. However, questions arise due to adoption of the above law. In our view, real consequences of the above law can be ambiguity of punishment for similar violations: the specific of the approved amendments consists in the fact that a judge at his/her discretion may choose either the minimum punishment or the maximum terms of imprisonment and ruinous penalties. The above may increase risks when working on the Russian market.

and contributions for the period of two years. See: Website of MK No. 26278 of July 12, 2013.

1 Actually, who will prohibit an individual from the near or far abroad residing for 180 days in the territory of the Russian Federation and having the status of a tax resident of the RF to become that "newly" registered entrepreneur claiming a two-year tax holiday?
By Federal Law No. 134-FZ, the entire complex of amendments was introduced into the Criminal Code of the Russian Federation providing for new types of economic violations and penalties (Article 8), including those for commercial graft (bribery), legalization (laundering) of especially large amounts of incomes, evasion from fulfillment of obligations as regards repatriation of funds in foreign currency or national currency of the Russian Federation, smuggling of currency and other. As was stated above, the magnitude of punishments for similar violations is too big.

For commercial graft (bribery), a punishment in the form of imprisonment, fine and ban on holding of certain offices may be applied. A fine is set in the range from $\mathrm{Rb} 5,000$ to $\mathrm{Rb} 5 \mathrm{~m}$, but the actual magnitude of punishment may vary from $\mathrm{Rb} 25,000$ to $\mathrm{Rb} 500 \mathrm{~m}$ in case the fine is calculated on the basis of the value multiple of the sum of a commercial graft (bribery) in an especially large amount (up to 100-multiple of the sum of the commercial graft). The mechanism of qualification of violations and setting of the concrete amount of the penalty is likely to be evident in the process of actual application of the set norms as the existing wording does not include special explanations on that issue.

The same comments concern other violations, as well: for example, punishment for legalization (laundering) of especially large amounts of cash funds or other property acquired by other persons by criminal means provides for compulsory labor with or without imprisonment for the term of up to five years or a ban on holding of office with a liability to pay a fine in the amount of up to $\mathrm{Rb} 500,000$ or in the amount of earnings or other income of the convict in the period of up to 5 years.

Another newly introduced form of violation is dodging from fulfillment of obligations as regards repatriation of cash funds in foreign currency or national currency of the Russian Federation. If a return of funds to the resident's account with an authorized bank did not take place, other residents who accepted the proceeds of that resident to their accounts will be punished depending on severity of the committed violation. The heaviest punishment provides for imprisonment for the period of five years with a fine in the amount of up to $\mathrm{Rb} 1 \mathrm{~m}$ or in the amount of a salary or other income of the convict in the period of five years or without such. Deeds are deemed committed in especially large amounts if such a sum of funds in foreign currency or the national currency of the Russian Federation as failed to be credited to the account or returned within a year exceeds $\mathrm{Rb} 6 \mathrm{~m}$ and that in especially large amount, $\mathrm{Rb} 30 \mathrm{~m}$.

As can be seen, qualification of violations by the grade of severity (for example, as regards commercial 
graft - an especially large violation is not determined; as regards legalization, an especially large violation amounts to $\mathrm{Rb} 6 \mathrm{~m}$; as regards evasion of repatriation it amounts to $\$ 30 \mathrm{~m}$ and as regards evasion of payment of customs duties in transportation of goods through the customs border of the Customs Union within the frameworks of the Eurasian Economic Union it amounts to $\mathrm{Rb} 3 \mathrm{~m}$ ) and the measure of punishment lacks a clear economic explanation.

Rather controversial norms were introduced in Part 1 of the Tax Code of the Russian Federation (Article 10). In particular, amendments provide for the fact that in case of "identification" by tax authorities in the course of examination that proceeds from sales of goods (jobs and services) of the resident entity were credited to accounts of subsidiaries the tax authorities are granted the right to collect the outstanding tax amount from accounts of those subsidiaries. Controversy of the provisions introduced into the Tax Code of the Russian Federation consists in the fact that subsidiaries are independent legal entities and according to the banking legislation the funds credited to their bank accounts are their own property no matter where they came from. Provision of the right to collect funds from accounts of third persons on the basis of a simple "identification" of the fact of origin of such funds by tax authorities is a violation of property rights. For example, in order to freeze and partially collect depositors' funds from accounts opened with banks in Cyprus, a law was passed to introduce a tax on deposits, that is, to transfer deposits into budget revenues and, consequently, in ownership of the state. In our case, tax authorities are granted the right to dispose of the property of other owners on the basis of facts "established" by tax authorities without investigation and a court decision. It is even more unclear why that norm was required to be introduced into the Tax Code of the Russian Federation. Proceeds in the form of funds credited to accounts of subsidiaries free of charge and not on the basis of business agreements are recognized as income which is subject to taxation, while such expenses of a parent company as are not based on business activities should not diminish the tax base. In other words, under the classical scheme of taxation the budget incurs no losses should any scheming related to transfer of funds take place. Probably, introduction of the above norm took place due to the fact that the notion of a consolidated group of taxpayers, that is, an artificially nominal taxpayer representing a community of formally independent legal entities which calculate and pay a profit tax on the consolidated balance was recently incorporated into the Tax Code of the Russian Federation and it has become much more difficult to identify the proceeds and costs of each participant.

By Federal Law No.134-FZ, provisions were specified as regards the procedure for suspension by the manager (deputy manager) of the tax authority of movement of funds in accounts of taxpayer-entity (a tax agent, persons engaging in private practice and individual entrepreneurs) with banks and electronic funds transfers. It is to be noted that banks have to submit to tax authorities the information on any accounts opened by legal entities, individuals-entrepreneurs and individuals at the request of tax authorities in case of tax audits or discovery of documents in other cases provided for by the Tax Code of the Russian Federation.

The number of persons which are obligated for the VAT purpose to prepare invoices and keep logs of the received and issued invoices and submit tax reporting includes those who are not taxpayers, but act on the basis of agency contracts on behalf and in the interest of a taxpayer (Article 12).

Substantial adjustments have been introduced into Federal Law No.115-FZ of August 7, 2001 on Prevention of Legalization (Laundering) of Incomes Received by Criminal Means and Financing of Terrorism. In principle, amendments to the above law are base ones for respective amendments introduced into other laws under review (Article 13).

The notion of a beneficiary owner- individual which ultimately directly or indirectly (through third persons) owns a customer-legal entity (has a prevailing interest of over $25 \%$ in its capital) or has an opportunity to control its activities has been introduced.

For the purpose of stepping up fight against terrorism, the notions of "blocking (freezing) of non-cash funds and uncertified securities" and "blocking of property by financial institutions" were introduced. In the first case, the authorities which carry out cash transactions are prohibited to carry out financial operations with customers' accounts (except for crediting of funds to those accounts), while in the latter one the owner of the property is prohibited to dispose of its own property. In case of blocking of funds and property, it is allowed to allocate $\mathrm{Rb} 10,000$ for maintenance of the customer's family if the latter has no means of subsistence.

Blocking is carried out in respect of an entity or individual (customers of financial institutions) included in the list of entities and individuals in respect of which there is information on their involvement in extremist activities or terrorism or in case there are enough grounds to suspect them of being involved in terrorist activities (including financing of terrorism) if there are no grounds to include them in the above list. 
Entities which carry out operations with funds and property (they include banks, insurance companies, investment funds and other financial institutions which carry out professional activities on the stock market, as well as individual entrepreneurs which are insurance brokers, individual entrepreneurs which carry out buying and purchase and sale of precious metals and precious stones, jewelry made of precious metals and precious stones and scrap of such articles, individual entrepreneurs which render intermediary services in carrying out transactions on purchase and sale of real property and other) are obligated to take measures immediately to freeze the customer's funds or property not later than one business day from the day of placement on the official Internet site of the authorized body of the information on inclusion of the customer (a legal entity or individual) in the list of persons involved or suspected of being involved in extremist activities or terrorism. One should promptly inform the authorized body of measures which were taken in accordance with the procedure established by the Government of the Russian Federation. If there is no reply from the authorized body within two days, blocking can be lifted.

The consequences of seemingly simple decisions, for example, those on suspension of operations on bank accounts for 2-3 days -- it is to be noted that decisions on "de-freezing" will be taken by the bank itself if the authorized body does not write anything, nor issues any instructions - may actually turn out to be rather serious. If the bank receives official instructions on freezing of the customer's funds or property, customers will have to make claims of ownership in accordance with the passed law to the state treasury by judicial means in the form of appeal against the decision of an interdepartmental coordination authority which carries out functions of prevention of financing of terrorism - on freezing (blocking) of funds or other property of the legal entity or individual. But who will pay on claims for a two-day delay in financial operations if the bank froze the funds, but no official order from the authorized authority was provided? The law does not regulate that issue. Probably, the bank will have to incur losses because it cannot prove legitimacy of such a delay.

Also, it is unclear why banks and other financial institutions are assigned the function of day-to-day on-line checking of customers. According to the law, banks and other financial institutions have to check customers once in three months, but, in reality, it turns out that they have to do it on a daily basis as the website of the authorized body can be updated, while under the above law banks and financial institutions are given one day only to block an account or property of the customer from the day its name appeared in the list on the website of the authorized body. Suppose, that issue can be solved by mean of purchasing of an automatic control system, but who pays for expenses related to that purchase? It seems that costs related to development, installation and maintenance of the above system in an operation mode will be allocated to expenses of Russian entities. In addition to the above, in accordance with the law under review a bank (or other financial institution) has to prepare a certificate on the next day after it refused to enter into an agreement or canceled an agreement with a suspicious customer explaining for what reasons and whom it refused to and what suspicious accounts were closed. The volume of correspondence is likely to be too big.

No less controversial are provisions of the law to the effect that submission at the request by the authorized body of the information and documents is not a violation of official, banking, tax and commercial secret and secret of communications (as regards the information on postal bank transfers) and the legislation of the Russian Federation in the sphere of personal data. As international agreements prevail over the domestic legislation of the Russian Federation, probably, it is expedient to wait for the findings of international experts as regards compliance of the regime that was introduced with rules of operation in the WTO conditions because the above regime does not exclude the responsibility to submit to the Russian authorized body the information on deals, including those transacted by foreign customers.

Among other amendments made to Federal Law No.134-FZ of June 28, 2013, it is worth mentioning amendments to the Law on Banks and Banking Activities. It is established that on the basis of decisions of judicial authorities with absence of the sufficient data for initiation of a criminal case banks have to provide the information on their customers and their accounts at the request of officials of the agency which is authorized to carry out investigative activities (Article 1). It seems the legislator tried to resolve the conflict that way between the investigative committee and the prosecutor's office. Lacking sufficient grounds for initiation of a criminal case, investigators may turn to a court and not to the prosecutor's office to obtain access to the required information. A question arises on what basis courts have the right to permit investigators to obtain the information without a criminal case being initiated? It seems a radical demolition of the system of investigation, that is, direct access to the judge with bypassing of the prosecutor's office increases considerably the potential and rights of the Investigative Committee. 
The volume of information provided by banks to tax authorities - it also concerns the information on accounts, deposits and transactions of individuals which carry out activities without establishing a legal entity and other individuals - has increased.

Amendments were introduced into the tax legislation. Tax authorities are obligated to submit to state agencies specified by orders of the President of the Russian Federation and documents of the Government of the Russian Federation the information on incomes and expenditures of employees of entities with state participation and members of their families.

Amendments were introduced into the Law on Organization of Insurance Business, the Law on the Stock Market and the legislation on share investment funds, nongovernment pension funds and micro-financial activities and micro-financial entities to the effect that persons in the period they used to be sole founders of such insurance and financial institutions licenses were withdrawn from those companies and a period of less than three years have passed since that time, as well as persons with an outstanding conviction (Article 3, Article 7, Article 9, Article 11 and Article 19) are prohibited to hold executive offices in the above entities and management companies. For the purpose of keeping record of persons in respect of which there are effective resolutions on disqualification, formation of the register of disqualified persons has been envisaged. Keeping of the register of disqualified persons is carried out by the federal executive authority authorized by the Government of the Russian Federation.

In case of an outstanding conviction in the sphere of economic activities, an individual is not in a position to dispose directly or indirectly of the capital of the insurance company or an entity which is a stock market professional participant or management company of the investment fund or a micro-financial entity in the volume exceeding $10 \%$. All the equities - owned by such a person - in excess of the above limit do not take part in the voting.

Persons with an outstanding conviction for crimes in the sphere of economic activities or crimes against state government cannot be managers, members of the board of directors (supervisory council), chief accountants of leasing companies, either.

The Civil Code of the Russian Federation includes norms which protect bona fide use of the data of the state register (Article 4). A legal entity is obligated to compensate damage caused to other participants in civil transactions in case of untimely provision of the data or provision of invalid data to the unified state register of legal entities (USRLE). In its turn, the damage caused by an illegal refusal in state registration of a legal entity, infringement of state registration and inclusion in the USRLE of invalid data are subject to indemnification at the expense of the state ${ }^{1}$.

By amendments introduced into the Civil Code of the Russian Federation, banks are permitted to cancel unilaterally a bank account agreement after 60 days from the day of notification of the customer in writing (an agreement is subject to termination in cases established by the legislation). Account balances unclaimed by the customer are transferred to a special account with the Bank of Russia (Article 6).

By relevant technical amendments introduced into the Code of Criminal Procedure of the Russian Federation (Article 16) and the Administrative Offences Code of the Russian Federation (17), penalties have been set for non-compliance with the legislation on blocking of customers' funds and property, in particular:

1) non-compliance with the legislation as regards blocking of funds or other property or suspension of operations with funds or other property implies an administrative penalty for officials and entities in the amount of $\mathrm{Rb} 30,000-\mathrm{Rb} 40,000$ and $\mathrm{Rb} 300,000-$ 500,000 , respectively, or administrative suspension of the entity's activities for the term of 60 days;

2) a failure to submit to the authorized authority at its request the information on operations of customers and beneficiary-owners of customers or the information on movement of funds on the customers' account (accounts) which information is available to the entity which carries out operations with funds and property implies charging of an administrative penalty in the amount of Rb 300,000-500,000 from the legal entity;

3) a failure to declare or unfair declaration by individuals of funds and (or) cash instruments which are transferred through the customs border of the Customs Union implies an administrative penalty for an individual in the size of single to double sum of the undeclared amount of cash funds and (or) the value of money instruments or confiscation of the item of an administrative violation.

In addition to the above, due to the position of the Constitution Court in respect of limitations in application of provisions as regards subsidiary responsibility of persons who control the business and let it go bankrupt amendments were introduced into the Federal Law on Insolvency (Bankruptcy) which is under review. In particular, a provision was introduced into the text of the law to the effect that the size of the property responsibility of the person who controls the debtor can be reduced if the former proves that the extent of the

1 It is to be noted, however, that it remains unclear what is considered a loss for the purpose of application of the above norm? And how can the party which was caused damage prove the size of the damage which is subject to indemnification at the expense of the state? 
damage caused to the property rights of the creditors due to the fault of that person is considerably lower than the amount of the claims which are to be met at the expense of that person.

Among other regulatory documents, it is important to single out the following:

1. By Resolution No.16-P of July 2, 2013 of the Constitution Court of the Russian Federation a decision was passed as regards legitimacy to change directly in the course of the court hearings accusations so that the position of the person on trial is made worse. According to the view of the Constitution Court of the Russian Federation, a lack of such legitimacy in the existing legislation precludes "independent and free choice by the court of criminal law norms which are subject to be applied in cases when the court comes to the conclusion that the actual circumstances stated in the indictment, bill of particulars and accusatory resolution point to the fact that in the deeds of the accused there is evidence of a worse crime or when in the course of preliminary hearings or court proceedings the court established actual circumstances which constitute grounds to qualify deeds as a worse crime". It is believed that the decision is of a general nature and can be applied in arbitration practice.

2. By Federal Law No.152-FZ of July 2, 2013, amendments were introduced into Chapter 23 and Chapter 26 of the Tax Code of the Russian Federation (the individual income tax and the severance tax, respectively).

It is specified by the law that the composition of income liable to the individual income tax includes income received in the Russian Federation from copyright and related rights and income from utilization of copyright and related rights outside the Russian Federation.

The income in kind (official uniform and equipment other than principal items) received by volunteers within the frameworks of agreements on fulfillment free of charge of jobs and rendering of services in accordance with the legislation on charitable activities and legislation of physical culture and sport in the Russian Federation is exempted from taxation.

Amendments were introduced into the rules of payment of the severance tax. A reduced ratio of 0.1 on subsoil plots where reserves of ferrous metal ores produced by means of underground mining methods amount to over $90 \%$ of reserves of ore of that plot is applied to the tax rate applicable in production of amenable iron of nonferrous metals (4.8\%).

3. By Federal Law No.153-FZ of July 2, 2013, amendments were introduced into the procedure - set by the Tax Code of the Russian Federation - for appealing of acts by tax authorities on bringing taxpayers to responsibility.

In particular, it is established by the law that nonregulatory acts of tax authorities and actions and inaction by tax authorities' officials can be appealed against in court only after they were appealed against at a higher tax authority. Acts of tax authorities and actions and inaction by their officials can be appealed against in court only if a decision on the appeal (petition of appeal) was not taken by a higher tax authority within the deadlines set by Article 140 (6) of the Tax Code of the Russian Federation.

An appeal is submitted to a higher tax authority through a tax authority whose non-regulatory acts and actions and inaction by officials are appealed against. Within three days from the day of submission of such an appeal, the tax authority has to direct it with all the materials enclosed to a higher tax authority for consideration and decision-taking. An appeal to the federal executive authority (the Federal Tax Service of the Russian Federation) which is in charge to carry out control and supervision in the sphere of taxes and duties can be submitted within three months after the day the senior management of the relevant territory tax authority has passed a decision on the appeal if the taxpayer is not satisfied with that decision. Should the taxpayer fail to submit for good reason an appeal within the above period, that period can be renewed.

4. By Federal Law No. 212-FZ of July 23, 2013, the wording of the provision as regards the property tax rebate granted to individuals within the frameworks of the individual income tax was specified.

The above law has resolved the two important issues. Firstly, it extended the right to receive the unutilized portion of the property tax rebate in purchasing of the housing for the first time to all the subsequent instances of buying of housing up to complete utilization of the property tax rebate ( $\mathrm{Rb} 2 \mathrm{~m})$. Secondly, it eliminated inequality in the rights of people to receive a fair rebate in buying of real property on the secondary market and by means of mortgage. Due to amendments to the law, the amount of the rebate as regards payment of interests under the loan (credit) agreement was increased to $\mathrm{Rb} 3 \mathrm{~m}$ (against $\mathrm{Rb} 2 \mathrm{~m}$ in case of a standard rebate) which is fair considering the size of the interests on mortgage lending.

The wording of the law on taxation of the income in the form of payments to individuals due to their exit from the number of the company's participants, liquidation of the company and reduction of the par value of shares (interests) was specified. The former wording determined the income as the total sum of the returned deposit (contribution) to the authorized capital (fund) which situation resulted in an ambigu- 
ous interpretation of the taxable income which in general understanding should be determined with deduction of expenses related to its receipt. Now, the situation is cleared up and Article 220 of the Tax Code of the Russian Federation is supplemented with a norm providing for deduction of the funds which were earlier contributed by the taxpayer to the authorized capital (in payment of the acquired share or interest).

5. By Federal Law No.215-FZ of July 23, 2013, the range of tax privileges for entities of culture and art has been expanded and the procedure for accrual of depreciation on capital assets specified. Services related to exhibition of museum articles and collections, organization of exhibitions and showing of plays, concerts and other performances outside the place of location of the entity are exempted from payment of VAT. If such entities are budget-funded institutions, the procedure for advance payment of the profit tax is canceled for them. The above entities are granted the right to write down expenses in full volume on modernization, completion and overhaul of capital assets incurred as a result of entrepreneurial activities to costs as of the day of commissioning, that is, not to apply the general procedure for depreciation of such expenses.

6. By Federal Law No.248-FZ of July 23, 2013, amendments were introduced into the Tax Code of the Russian Federation in order to upgrade tax administration.

Application of digital technologies in carrying out by tax authorities of their functions (as regards submission of queries in an electronic format) has been expanded.

The deadlines for reconcilement of the tax debt have been specified. The certificate on arrears is to be submitted within five days from the day of the query, while that on penalties, fines and interests, within 10 days from the day of a query from the taxpayer (tax agent).

The text of the Tax Code of the Russian Federation is supplemented with a mechanism of suspension and withdrawal of documents on collecting of funds from accounts of taxpayers in case liabilities have been partially paid by the taxpayer, as well as in other cases established by the law with a subsequent adjustment of the size of recovery claims made by tax authorities to accounts of taxpayers.

The procedure for tax calculation in case of insufficiency of funds in the account of the taxpayer or correspondent account of the bank was introduced into the text of the Tax Code of the Russian Federation.
In case of change in the deadlines for fulfillment of obligations as regards payment of taxes and in other cases provided for by the Code, a tax liability can be ensured by a bank guarantee. A bank guarantee should be an irrevocable and nonnegotiable one; it is to be issued by a bank which is included in the list of banks whose guarantees are accepted by the Ministry of Finance of the Russian Federation; the bank's capital should amount to minimum $\mathrm{Rb} 1 \mathrm{bn}$; the term of the bank guarantee should expire not earlier than in six months from the day of expiry of the established period of fulfillment by the taxpayer of its tax liabilities; the bank guarantee should cover the amount of arrears and penalties; obligation as regards the banking guarantee is subject to fulfillment by the guarantor within 5 days from the day of receipt of a claim to pay the funds.

In the text of the law, the mechanism of attachment on the taxpayer's property is specified. A norm permitting a tax authority at the request of a taxpayer - legalentity in respect of which a decision on attachment was taken to replace attachment on its property by a pledge has been introduced.

The procedure has been specified for registration and de-registration with a tax authority of a liable partner of a consolidated group, management companies of closed unit investment funds, entity-participant in agreement on partnership, individual-taxpayer, an entity at the place of registration of a separate structural unit and other.

The list of conditions where the arrears are recognized as bad ones has been expanded. Deemed as such is resolution of a marshal to stop a court enforcement action due to infeasibility to recover the arrears. It is to be noted that two more conditions are to be observed: five years should pass from the day the arrears arose and its sum together with penalties and fines should not exceed the amount of claims - set by the legislation of the Russian Federation on insolvency (bankruptcy) - to the debtor in order to initiate bankruptcy proceedings. It is to be reminded that as regards legal entities the sum of such claims amounts to $R b 100,000$, while as regards entrepreneurs, to $\mathrm{Rb} 10,000$.

In the text of the Tax Code of the Russian Federation, a procedure for registration for taxation purposes or execution of a patent for migrants in case of their employment was introduced. 